\title{
Particle Deposition \\ in the Present and Holocene Black Sea
}

\author{
By Bernward Hay and Susumu Honjo
}

\section{About 5000-7000}

years ago the Black

Sea was a fresh water

lake.
$\mathrm{T}$ HE BLACK SEA represents a fascinating environment for detailed particle deposition studies. The basin is comparatively small, yet over $2,000 \mathrm{~m}$ deep. It is nearly completely enclosed and only connected through the shallow Bosporus to the world's oceans. The hydrography and the sediment input parameters from the surrounding rivers are comparatively well known. The seasonal changes in sedimentation are preserved in the bottom sediments in the form of laminated sequences, since the absence of oxygen in the deep water interface prohibits bioturbation. Once deposited, the sediments in the abyssal Black Sea remain in place; redistribution processes on the basin floor are comparatively insignificant.

The current biogeochemical conditions of the Black Sea, however, are not stable. About 5000-7000 years ago the Black Sea was a fresh water lake. With the inflow of saline Mediterranean water through the Bosporus, the salinity gradually increased until reaching its present value of about $18 \mathrm{ppt}$ in the surface waters. The constant change in salinity forced constant readjustment of the planktonic assemblages in the struggle for the adaptational edge. The salinity may not have risen linearly. Due to the delicate balance between riverine fresh water and Mediterranean saline water inflow as a function of sea level and climate variability, there may have been a significant second-order component in the salinity increase. Temporal changes in precipitation and rainfall patterns most likely left their mark in the accumulation rates of terrigenous matter in the bottom sediments (e.g., Hay, 1988).

The laminated sediments in the abyssal Black Sea were discovered during one of the first scientific cruises in the Black Sea about 100 years ago (Andrusov, 1890). The high concentration of the coccolithophorid species Emiliania huxleyi in the white laminae was not recognized, however, until the first international landmark cruise with the R/V Atlantis $I I$ in 1969 (e.g. Degens and Ross, 1974). The uppermost sediment sequences were then grouped into sediment units I (coccolith ooze) and II (sapropel) (Ross and Degens, 1974). The R/V Atlantis II cruise was succeeded by a shorter $\mathrm{R} / \mathrm{V}$ Chain cruise in 1975, when a number of undisturbed laminated cores

Bernward Hay and Susumu Honjo: Woods Hole Oceanographic Institution. Woods Hole, MA 02543. were taken with a specially engineered gravity corer for varve chronological studies (Degens et al., 1980). In the same year, the R/V Glomar Challenger Leg $42 \mathrm{~B}$ also contributed further in understanding the geological evolution of the Black Sea in relation to the history of the Euro-Russian Massif (Ross and Neprochnov et al., 1978).

In the past, continuous information on the seasonal variability in biogenic particle flux was sketchy, possibly because of "the preference of planktonologists of taking samples largely during the good weather season" (Sorokin, 1983, p. 269), i.e. summer/fall. The process of formation of the black and white laminae, however, very strongly depends on the seasonal variability in particle generation and transport processes. White laminae are almost exclusively composed of E. huxleyi, while black laminae consist largely of terrigenous matter. Thus, understanding the seasonal particle flux in the Black Sea is critical for establishing the link between particle sources, water column processes, and the laminated sediment record. Understanding these recent processes is necessary to more precisely reconstruct sources and processes from the sediment record over the last several thousand years.

Recently, we investigated the seasonal particle flux in the water column in a feasibility study in the southwestern Black Sea with time-series sediment traps from 1982-1988 in collaboration with Dokuz Eylül Üniversity in Izmir, Turkey, the University of Hamburg, and Woods Hole Oceanographic Institution. Sediment traps were moored consecutively at two sites (sites BS and BSC) at a water depth of $250 \mathrm{~m}$ and $1200 \mathrm{~m}$ (Fig. 1, p. 28). Conclusions from these first sediment trap studies, integrated in the discussion below, provided new insights into the particle deposition processes in that region of the Black Sea (e.g. Honjo et al., 1987; Izdar et al.. 1987; Degens, et al., 1984).

\section{The R/V Knorr Cruise}

The interdisciplinary R/V Knorr cruise in the spring of 1988 provided an excellent opportunity to test the preliminary conclusions and hypotheses on the particle deposition in the central regions of the Black Sea as well. Accordingly, the focus of Leg 1 was the biogeochemical variability in particle deposition in the present and past from source to burial, 

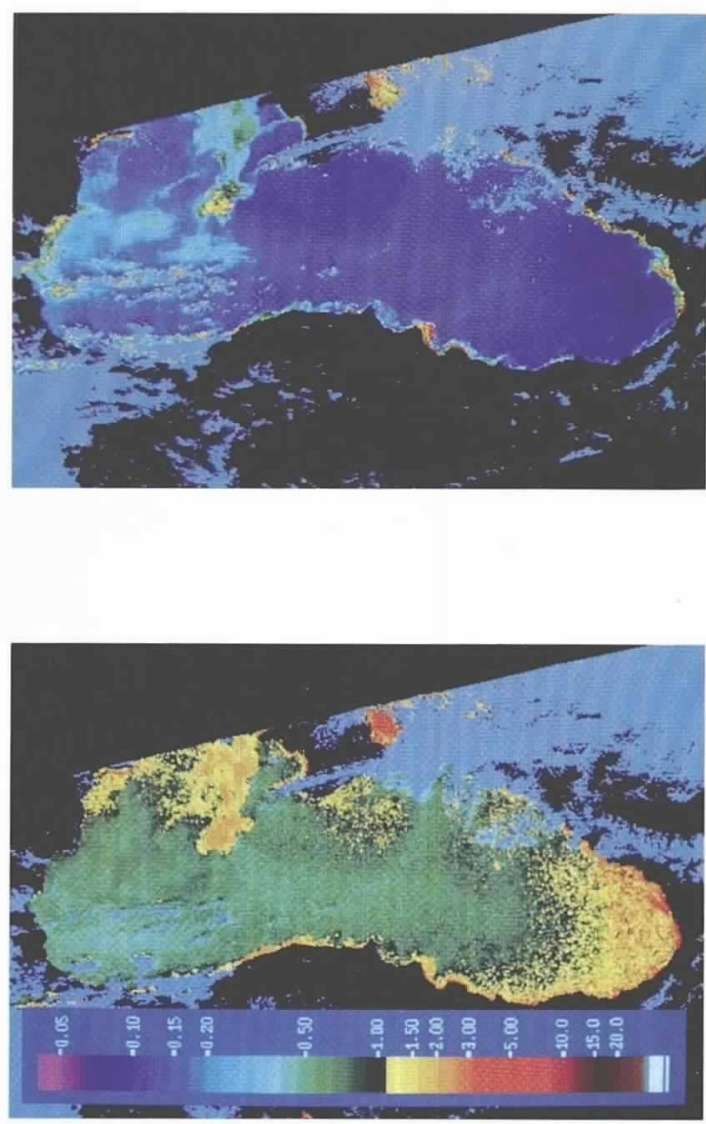

Fig. 2: Coastal Zone Color Scanner (CZCS) satellite image from the Black Sea from October 7, 1980. The top image represents the atmospherically corrected channel $3(552 \mathrm{~nm})$; the bottom image represents the calculated pigment concentration (in $\mathrm{mg} \mathrm{m}^{-3}$ ) in the Black Sea (for technical details of the processing, see Müller-Karger et al., 1989). The high pigment concentration in the northwestern Black Sea most likely represents an $\mathrm{E}$. huxleyi bloom; in contrast to most phytoplanktonic organisms, E. huxleyi is characterized by high spectral reflectance in all CZCS channels in the visible light spectrum (Holligan et al., 1983). Therefore, the high pigment concentration in the southeastern Black Sea is related to different planktonic organisms. The high particle concentration along the southern Black Sea coast in channel 3 (top) is caused by terrigenous sediment input from the adjacent Anatolian rivers.

(CZCS image processed by Frank Müller-Karger, University of South Florida)

with high temporal and spatial resolution. Particles from the water column were collected and monitored by a large array of instruments, including a flux camera, mini-rover, particle pump, and a transmissometer. Time-series sediment traps were deployed for one year and three months in the central regions of the Black Sea (sites BSK1-3; Fig. 1, p. 28). Thirty large $(50 \mathrm{~cm})^{3}$ box cores were collected, many with the preserved sediment/water interface (fluff layer). The deeper sediments were collected in 53 giant gravity cores with a maximum length of $6 \mathrm{~m}$. Sediment core material has been stored constantly under refrigerated conditions at $8-9^{\circ} \mathrm{C}$, the ambient bottom water temperature of the Black Sea. Logistical details and scientific observations of Leg 1 are published in Honjo and Hay et al. (1988).

Discussed below is a brief summary of our current knowledge of the particle deposition from source to burial in the present and past Black Sea. This discussion includes results from earlier feasibility studies as well as new initial results from the R/V Knorr cruise.

\section{Particle Sources}

Dominant particle sources are the rivers and biological production in the surface waters. The eolian particle supply is comparatively small (Lebedeva and Vostokov, 1984). About 55\% of the terrigenous matter is supplied by the Danube alone; about $25 \%$ is supplied by rivers in the southeastern Black Sea (Shimkus and Trimonis, 1974). A substantial contribution of the organic matter buried in the sediments is of terrigenous origin (e.g. Deuser, 1972). The terrigenous matter deposition is highest closer to shore. This observation was also made with the sediment traps in the southwestern Black Sea. At the nearshore trap site, BS, lithogenic matter composed about $34 \%$ of the total annual particle flux but only about $18 \%$ at the offshore site, BSC. The abyssal floor sediments contain only about one-third terrigenous matter (Hay, 1988).

The seasonal primary production pattern in the Black Sea is bimodal. Diatoms predominantly bloom in spring, while E. huxleyi, and to a lesser degree dinoflagellates, predominantly bloom in summer and fall. The seasonal and spatial variability in biological production in the Black Sea, especially in the central regions, is not well understood, however. Primary production is believed to be highest over the Danube shelf and along the Caucasus margin (Finenko, 1967). This conclusion is supported by Coastal Zone Color Scanner (CZCS) satellite imagery (Fig. 2). Biological production is also higher closer to shore at the different sediment trap sites.

The likely cause for spatial variability in productivity is differences in nutrient availability. Nutrients are mainly supplied to the surface water by upwelling of the nutrient-rich deeper water and by riverine nutrient supply (Glenn and Arthur, 1985). Strongest upwelling occurs along the margin of the clockwise Black Sea gyre, where current velocities are highest (Grasshoff, 1975). Nearshore upwelling may cause a higher supply of nutrients, which explains the longer plankton bloom periods observed at trap site BS (Hay et al., manuscript in review). In contrast, at site BSC, plankton blooms occur during short sporadic bursts, lasting less than a month but depositing more than half of the annual particle flux.

One such plankton burst may be seen on the CZCS image in the western Black Sea from October 7, 1980 (Fig. 2). The plankton bloom possibly represents a large E. huxleyi bloom (Holligan, personal commu-
$U_{n}$ derstanding the seasonal particle flux in the Black Sea is critical for establishing the link between particle sources, water column processes, and the laminated sediment record. 


\section{R/V Knorr Black Sea Cruise 1988, Leg 1}

\section{$D_{\text {iatoms }}$}

predominantly bloom

in spring, while $E$

huxleyi, and to a lesser

degree dinoflagellates,

predominantly bloom

in summer and fall.

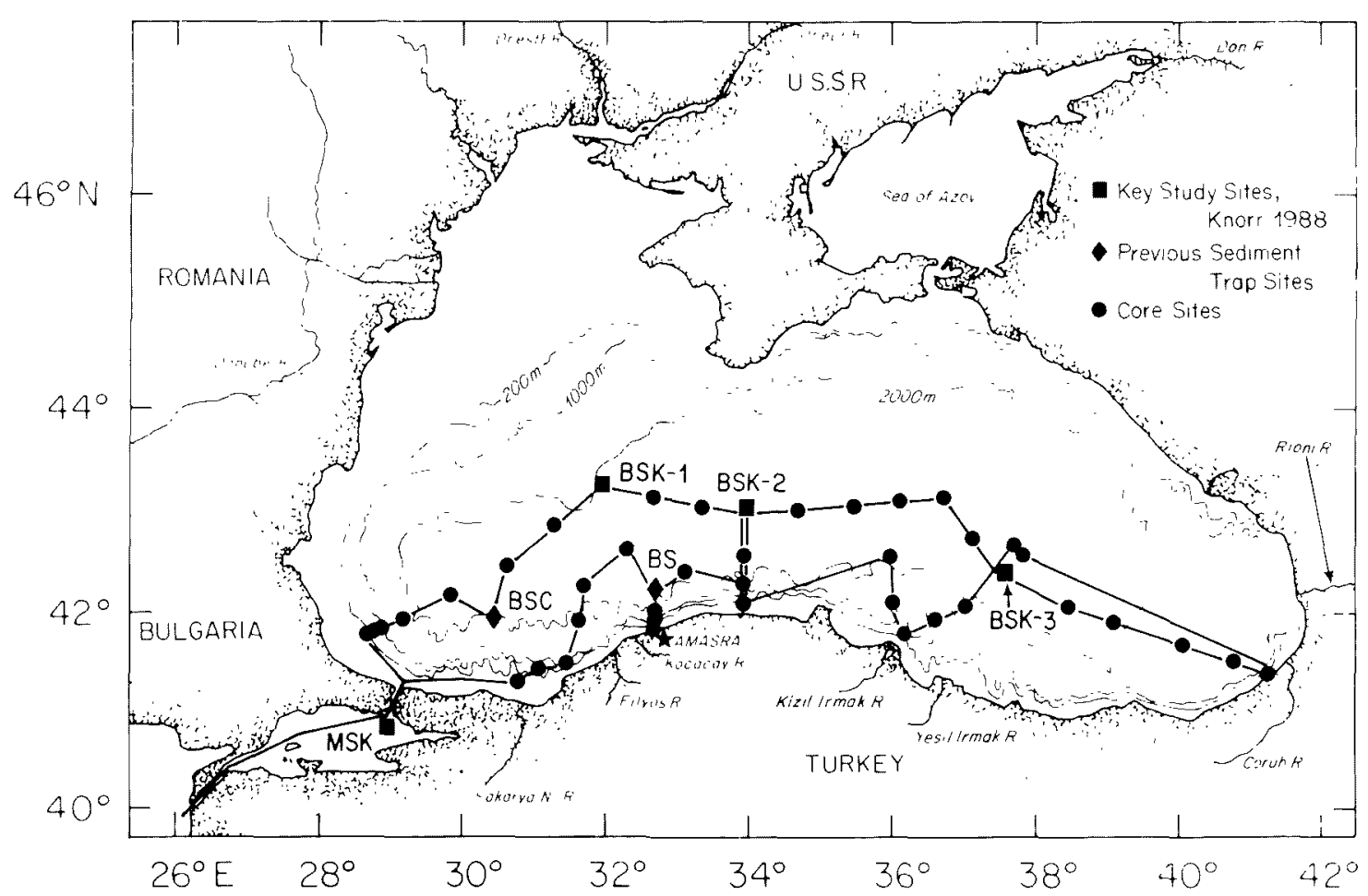

Fig. 1: Cruise track of Leg I of the R/V Knorr 134-8 to the Black Sea. spring 1988. Along the cruise track about 80 sediment cores were collected. Sites BS and BSC are time-series sediment trap sites studied between 1982 and 1988 . Sites BSKI-3 are trap sites currently being studied. Station numbers and positions are listed in detail in Honjo and Hay, et al. (1988).

nication). Interestingly, the simultaneous high pigment concentration in the southeastern Black Sea appears to be related to other planktonic organisms (Fig. 2). The seasonal and regional variability in biological production in the central Black Sea is not understood at present. This question, however, is intriguing, given the CZCS-observed variability in production in surface waters, on one hand, yet the high degree of lateral continuity of the laminated sediments in most of the abyssal regions of the Black Sea on the other hand. This question is now being addressed with the currently deployed sediment trap mooring arrays at sites BSK1-3 (Fig. 1) which are scheduled to be recovered this fall by the Turkish R/V Koca Piri Reis of the Dokuz Eyluil Üniversity, İzmir.

\section{Particle Transport}

One of the striking observations during the R/V Knorr cruise was the basinwide correlation of the recent laminated sediment sequences, extending over nearly $1000 \mathrm{~km}$ (Honjo and Hay et al.. 1988). In the uppermost Unit I. deposited over the last 1000 years, the black and white laminae consist dominantly of terrigenous matter and coccolith ooze, respectively. Considering that terrigenous particles originate from point sources (river mouths), and biological production appears to occur regionally in a sporadic manner
(Fig. 2), particle distribution and transportation mechanisms must play an important role in order to explain the excellent basinwide correlation of the laminated sequences.

The present hypothesis is based largely on sediment trap results from the feasibility study in the southwestern Black Sea. At sediment trap site BSC, the removal of terrigenous matter occurred dominantly during the intense plankton bursts in spring and summer/fall. with fecal pellets and "marine snow" aggregates as the main transporting agents. Similar observations were made during the brief summer deployment at site BSK2 (Fig. 3, p. 29). These observations suggest that fine-grained terrigenous matter may remain in suspension in the surface water for several months. This may be sufficient time for transport of the suspended matter across the basin before it is removed by settling biogenic particle aggregates during sporadic plankton blooms.

This hypothesis is also supported from the sediment trap samples of the summer deployment at site BSK2. The total particle flux at this site ranges from 2 to $71 \mathrm{mg} \mathrm{m}^{-2} \mathrm{~d}^{-1}$ (Fig. 3). The sampling interval was 5.75 days. However, despite the large range in total flux, the concentration of terrigenous matter remained approximately the same in all samples, sug- 
Particle Flux at R/V Knorr Site BSK2 Summer Deployment 1988

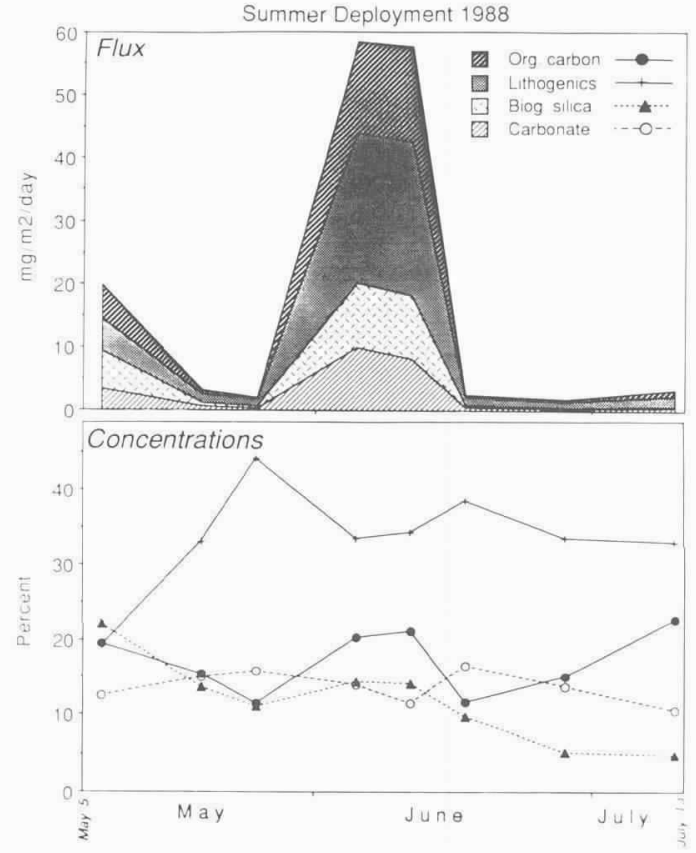

Fig. 3: Sediment trap results from site BSK2 $\left(42^{\circ} 58^{\prime} \mathrm{N}\right.$, $\left.34^{\circ} 00^{\prime} \mathrm{E}\right)$. Site BSK2 was the site for a $21 / 2$ month long summer deployment between Leg 1 and Leg 5 of the $R / V$ Knorr cruise.

gesting removal of terrigenous particles by aggregation into marine snow particles.

Lateral transport deeper in the water column may also play an important role for sedimentation in the Black Sea. Fine-grained turbidites typically up to 20 $\mathrm{cm}$ thick are interbedded in the laminated sediment.
These turbidites are locally confined; they typically were not traced over long distances despite the extensive coring effort. Surprisingly, there was a lack of noticeable erosion of the underlying laminated sediments. It is conceivable that such large volumes of sediment were transported laterally as a particle cloud in the deep water column before settling out. Systematic investigations of the new R/V Knorr cores will be necessary, however, to fully comprehend the role of lateral transport during turbidite deposition.

\section{Particle Burial}

After settling to the basin floor, particles first become part of a flocculent layer on the basin floor (fluff layer). This layer is several centimeters thick. Most of the biogeochemical transformations occur within this layer, which was sampled for the first time in the Black Sea. In this layer the organic carbon is decomposed anaerobically from over $14 \%$ measured in sediment traps annually (see also Fig. 3) to about $4 \%$ in the recent sediments (Unit I; Fig. 4). Possibly, the transition from the typically grayish-brown particle flux to distinct black and white laminated sediment occurs within this transition zone (Honjo and Hay et al., 1988).

Since the development of permanent anoxic conditions in the Black Sea 5000-7000 years before present (B.P.), particle deposition changed considerably. Previous studies suggested that primary production from about $3000-5000$ years B.P. was at a peak (e.g. Glenn and Arthur, 1985; Hay, 1988). This is indicated by higher organic carbon accumulation rates, and $\partial{ }^{13} \mathrm{C}$ values closer to marine values (Deuser, 1972; Calvert and Fontugne, 1987). The sea level in the Black Sea may have been several meters higher than today (Fedorov, 1978).

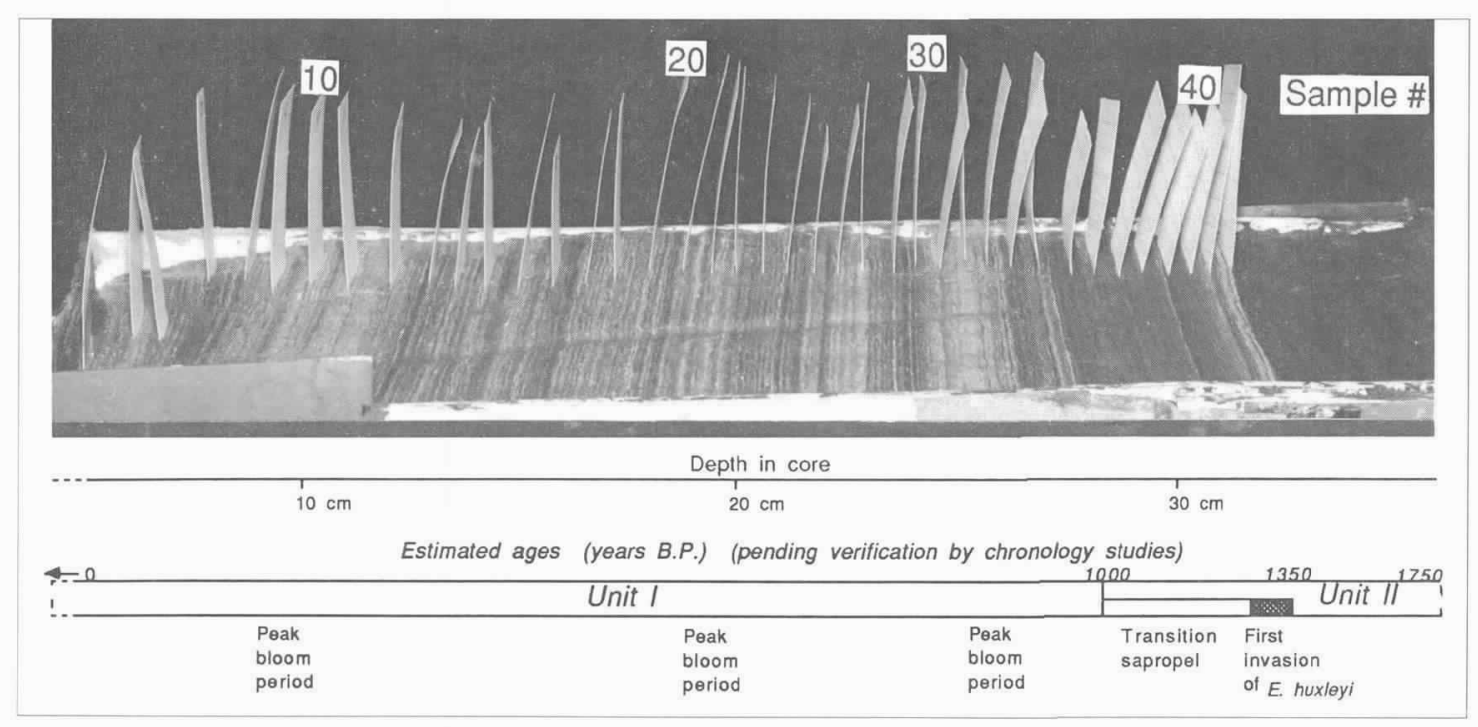

Fig. 4: Box core collected at site BSK3, identical to site 1474 of the R/V Atlantis II cruise in 1969 (Degens and Ross, 1974). (The markers in the sediment represent sediment subsampling markers.) The first invasion of $\mathrm{E}$. huxleyi (at sample 43) occurred within Unit II. After several decades of coccolith ooze deposition, sapropel deposition returned (at about sample 41) for several centuries. Within Unit I there are several time periods of more intense E. huxleyi deposition, lasting up to 200 years each. The current age assignment is an estimate based on varve counting by Degens et al. (1980). 


\section{$\mathrm{Ca} / \mathrm{Al}$ Ratio, Eastern \& Western Black Sea}

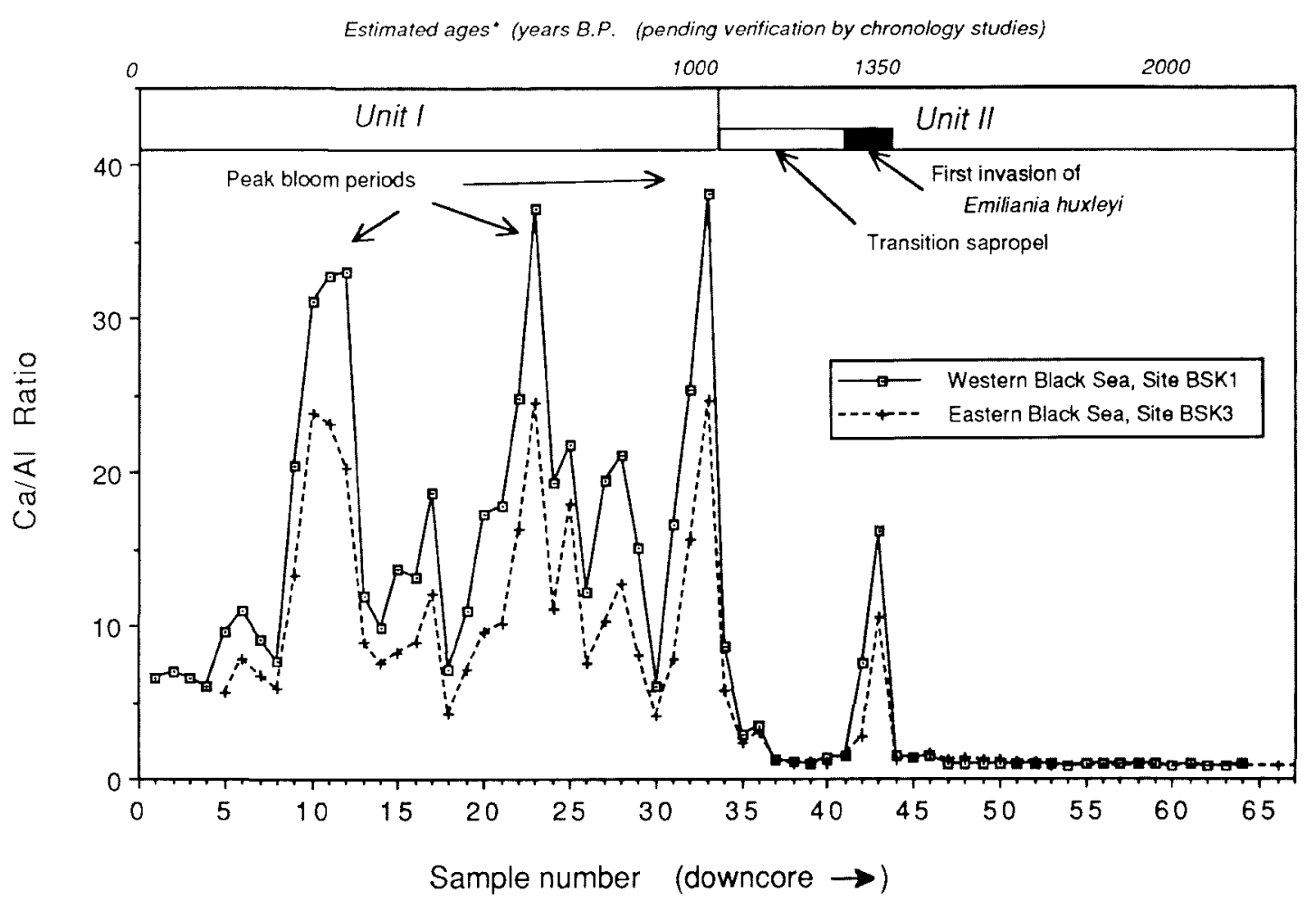

about 50 years....

E. huxleyi invaded the

Black Sea for a second

and final time about

$300-400$ years later.

Fig. 5: CalAl ratio of cores from the eastern and western Black Sea. The Ca/Al ratio essentially represents the ratio between the accumulation of $\mathrm{E}$. huxleyi and terrigenous matter; terrigenous carbonate accumulation is comparatively low and is in almost constant proportion within the terrigenous matter as seen by the CalAl ratio in the coccolith-free Unit II. Other data, such as the C IAl ratio (Authur et al., 1988; Neff et al., 1988) as well as the over $10 \%$ higher thickness of Unit I at site BSKI suggest that E. huxleyi production was consistently higher in the eastern than in the western Black Sea. The parallel pattern of both curves is a reflection of the near-perfect correspondence of the laminated sequence throughout the abyssal Black Sea.

About 1000-3000 years B.P. the terrigenous matter accumulation rates increased, suggesting higher precipitation in the drainage area of the rivers surrounding the Black Sea (Hay, 1988). Biological productivity in the surface waters of the Black Sea during this period may have decreased, as reflected by the lower carbon accumulation rates. The lower carbon accumulation rates were not caused by lower terrigenous carbon input, since the $\partial^{13} \mathrm{C}$ values of this time period are closer to terrigenous values (Deuser, 1972: Calvert and Fontugne, 1987).

The gradual change in salinity from fresh (over 5000 years ago) to brackish presently led to constant changes in the planktonic assemblages. The most visible change in the planktonic assemblage occurred with the invasion of E. huxleyi, which increased the sedimentation rate in the Black Sea by a factor of three. The first invasion of $E$. huxleyi occurred about 1500 years B.P., but only lasted for about 50 years (ages pending detailed chronological study). E. huxleyi invaded the Black Sea for a second and final time about 300-400 years later. (The second and final invasion marks the stratigraphic boundary between Unit I and Unit II (Ross and Degens, 1974).) Causes for the temporary disappearance of E. huxleyi are currently not understood. A likely reason could be a change in salinity as a result of higher precipitation. The lowest salinity at which E. huxlevi is found is about $11 \mathrm{ppt}$ in the Sea of Azov. It is conceivable that the first invasion was triggered by salinity levels just tolerable for $E$. huxleyi. A small reduction of this salinity level due to increased freshwater input (or reduced saline Mediterranean inflow water) could have led to a temporary loss of the just previously gained adaptational edge of $E$. huxleyi.

Particle deposition during Unit I was marked by periods of higher E. huxleyi production (peak bloom periods). This is suggested by higher $\mathrm{Ca} / \mathrm{Al}$ ratios (Fig. 5). Good correspondence with higher organic carbon-to-aluminum $\left(\mathrm{C}_{\text {org }} / \mathrm{Al}\right.$ ) ratios (Arthur et al., 1988; Neff et al., 1988) indicates that the high $\mathrm{Ca} / \mathrm{Al}$ ratios are not caused by lower terrigenous input, since a considerable fraction of the buried organic carbon was supplied from land.

Primary production was consistently higher in the eastern Black Sea than in the western Black Sea. The same offset has been observed in the $\mathrm{C}_{\text {org }} / \mathrm{Al}$ ratio between these two basins, again suggesting that this difference is due to differences in production, not terrigenous input. 


\section{The Present as Key to the Past}

The results of the feasibility studies and the first results of the R/V Knorr cruise, Leg 1, already document the significance of integrating water column fluxes and the laminated bottom sediments for unraveling the depositional and environmental history of the basin. The extensive core collection and the time-series sediment trap data, as well as the successful collection of the sediment surface (fluff layer), will enable us now to examine the Holocene sedimentary history in the Black Sea in unprecedented detail. The biogeochemical analyses of the core and trap samples are closely integrated and are carried out on identical samples. These analyses include $\partial^{13} \mathrm{C},{ }^{18} \mathrm{O}$ and ${ }^{15} \mathrm{~N}$ isotopes (Arthur, Dean); detailed ${ }^{14} \mathrm{C}$ analyses with tandem accelerator mass spectrometry (Jones); varve chronology (Arthur, Neff, Hay); bulk chemistry and major, minor, and trace element chemistry (Honjo, Hay, Dean, Kempe, Konuk); sulfur (Nicholson, Arthur); marine snow (Asper); fecal pellets (Pilskaln); pore waters (Liebezeit); planktonic studies (Dale, Honjo, Hay); and possibly molecular stratigraphy for evaluation of climatic changes (alkenones, sterols; Brassell).

We anticipate that the final syntheses of the data will provide a comprehensive understanding of the detailed temporal and spatial variability in particle deposition in the Black Sea, in relation to climate, nutrient supply, and salinity changes.

Acknowledgements

We thank Drs. E. Izdar, T. Konuk (Dokuz Eylül Üniversity. Izmir, Turkey) and the Turkish Research Council as well as the National Science Foundation for their tremendous efforts to make this cruise possible. The research discussed in this paper was funded by the National Science Foundation (Grant No. OCE8417106, OCE-8614363) and the Office of Naval Research (Contract No. N00014-85-C-0001). Members of the scientific shipboard party of R/V Knorr 134-8, Black Sea Leg 1, who all contributed substantially to the success of this cruise, are listed in the article by Murray and Izdar (this issue). The manuscript mentioned in the text as "in review" is co-authored by B.J. Hay, S. Kempe, S. Honjo and T. Konuk. This is Woods Hole Oceanographic Institution Contribution \#6997.

References

Androsov, N. I. 1890: Predvarityel'nyi otchet ob uchastii v Chernomorskoy glubokomemoy ekspeditsii $1890 \mathrm{~g}$ (Preliminary accounts of participation in the Black Sea deepwater expedition of 1890). Izv. Russk. Geogr. ob* wa., 26. 398-409.

Arthur, M.A., W.E. Dean, B.J. Hay, S. Honjo, E.D. Neff, T. Konuk, and Shipboard Science Party. 1988: Lak Holocene Sedimentation and environmental history of the Black Sea: Preliminary results from R/N Knorr, 134-8 Expedition. Geol. Soc. Amer. Abstr. with Programs, 20 , A199.

Calvert, S. E. and M. R. Fontugne, 1987: Stable carbon isotopic evidence for the origin of the organic matter in the Holocene Black Sea sapropel. Chem. Geology, 66, 315322.

Degens, E. T., V. Ittekkot, S. Kempe, V. Asper and S. Manganini, 1984: Sedimentation mariner Schwebstoffe, untersucht mit Hilfe von Sedimentfallen. Unpubl. progress report. Universität Hamburg, F.R. Germany, $30 \mathrm{pp}$.

Degens, E. T. and D. A. Ross, editors, 1974: The Black SeaGeology, Chemistry, and Biology. Mem. Am. Assoc. of Petroleum Geologists, 20,633 pp.

Degens, E. T., W. Michaelis, C. Garrasi, K. Mopper, S. Kempe and V. A. Ittekkot, 1980: Warven-Chronologie und frühdiagenetische Umsetzungen organischer Substanzen holozäner Sedimente des Schwarzen Meeres. Neues Jahrbuch Geologisch-Palaeontologischer Monatshefte. $5,65-86$.

Deuser, W. G., 1972: Late-Pleistocene and Holocene history of the Black Sea as indicated by stable isotope studies. $J$. Geophys. Res., 77. 1071-1077.

Fedorov, P.V., 1978: The Pleistocene of the Pontic-Caspian Region (in Russian). Nauka, Moscow, USSR.

Finenko, Z. Z.. 1967: Primary production in southern seas. In: Problems of Bio-oceanography. V. A. Vodianitskii, editor, Naukova dumka, Kiev, USSR, 5-68.

Glenn, C.R. and M. A. Arthur, 1985: Sedimentary and geochemical indicators of productivity and oxygen contents in modern and ancient basins: The Holocene Black Sea as the "type" anoxic basin. Chemical Geology, 48, 325-354.

Grasshoff, K.. 1975: The hydrochemistry of landlocked basins and fjords. In: Chemical Oceanography, 2nd edition. J.P. Riley and G. Skirrow, editors, Academic Press, New York, 456-593.

Hay, B. J., 1988: Sediment accumulation in the central western Black Sea over the past 5,100 years. Paleoceanography, 4, 491-508.

Hay, B. J., M. A. Arthur, E. Neff, W. E. Dean, T. Konuk and S. Honjo, 1988: Late Holocene sediment accumulation in the abyssal Black Sea. EOS, 69, 1242.

Holligan, P. M., M. Viollier, D. S. Harbour, P. Camus and M. Campagne-Phillips, 1983: Satellite and ship studies of coccolithophore production along a continental shelf edge. Nature, 304, 339-342.

Honjo, S., B. J. Hay, S. Manganini, V. L. Asper, E. T. Degens, V. Ittekkot, S. Kempe, E. Izdar, Y. T. Konuk and H. A. Benli, 1987: Seasonal cyclicity of lithogenic particle fluxes at a Southern Black Sea sediment trap ștation. In: Particle Flux in the Ocean, E. T. Degens, E. Izdar. and S. Honjo, editors, Mitteilungen des Geologisch-Palaeontologischen Institutes, Universität Hamburg, 62, 19-40.

Honjo, S., B. J. Hay, and Shipboard Party, 1988: Temporal and spatial variability in sedimentation in the Black Sea: Cruise Report, R/V Knorr 138-4, Leg 1 April 16-May 7. 1988: Black Sea Sedimentation Data File, v. 2, Woods Hole Oceanographic Institution Technical Report WHOI88-35, and Piri Reis Intemational Contribution Series No. $6,156 \mathrm{pp}$.

Izdar, E., T. Konuk. V. Ittekkot, S. Kempe, and E. T. Degens, 1987: Particle flux in the Black Sea: Nature of the organic matter. In: Particle Flux in the Ocean, E. T. Degens, E. Izdar, and S. Honjo, editors, Mitteilungen des GeologischPalaeontologischen Institutes, Universität Hamburg, 62. $1-18$.

Lebedeva, L. P. and S. V. Vostokov, 1984: Studies of detritus formation processes in the Black Sea. Oceanology. 24 , 258-263.

Müller-Karger, F., C. R. McClain, T. R. Fisher, and W. E. Esaias, 1989: Pigment distribution in the Caribbean Sea: Observations from space. Progress in Oceanography, (in press).

Neff, E. D., M. A. Arthur, B. J. Hay, and W. E. Dean, 1988: Late Holocene evolution of anoxia in the Black Sea. EOS, 69 $1242 \mathrm{pp}$.

Ross, D. A., and E. T. Degens, 1974: Recent sediments of the Black Sea. In: The Black Sea-Geology. Chemistry, and Biology, Degens, E. T. and D. A. Ross, editors, Mem. Am. Assoc. of Petroleum Geologists, 20, 183-199.

Ross, D. A., Neprochnov, Y. P., et al., 1978: Initial Reports of the Deep Sea Drilling Project, 42B, Washington D.C., U.S. Government Printing Office, 1244 pp.

Shimkus, K. M. and E. S. Trimonis, 1974: Modern sedimentation in Black Sea. In: The Black Sea-Geology, Chemistry, and Biology. E. T. Degens and D. A. Ross, editors, Mem. Am. Assoc. of Petroleum Geologists, 20, 249-278.

Sorokin, Yu. I., 1983: The Black Sea. In: Estuaries and Enclosed Seas, Ecosystems of the World, 26. B. H. Ketchum, editor, Elsevier Sci. Publ., New York, 253-292. 